GMR

\title{
Prevalence of human papillomavirus, Chlamydia trachomatis, and Trichomonas vaginalis infections in Amazonian women with normal and abnormal cytology
}

E. Costa-Lira ${ }^{1,3}$, A.H.V.L. Jacinto², L.M. Silva ${ }^{3}$, P.F.R. Napoleão ${ }^{3}$, R.A.A. Barbosa-Filho ${ }^{3}$, G.J.S. Cruz ${ }^{5}$, S. Astolfi-Filho ${ }^{4}$ and

C.M. Borborema-Santos ${ }^{3}$

${ }^{1}$ Programa de Pós-Graduação em Biotecnologia, Universidade Federal do Amazonas, Manaus, AM, Brasil ${ }^{2}$ Programa de Pós-Graduação em Ciências Farmacêuticas, Universidade Federal do Amazonas, Manaus, AM, Brasil

${ }^{3}$ Laboratório de Diagnóstico Molecular, Centro de Apoio Multidisciplinar, Universidade Federal do Amazonas, Manaus, AM, Brasil

${ }^{4}$ Laboratório Tecnologias do DNA, Centro de Apoio Multidisciplinar, Universidade Federal do Amazonas, Manaus, AM, Brasil

${ }^{5}$ Departamento de Planejamento, Secretaria Municipal de Saúde de Manaus, Manaus, AM, Brasil

Corresponding author: E. Costa-Lira

E-mail: costa_eve@yahoo.com.br

Genet. Mol. Res. 16 (2): gmr16029626

Received January 25, 2017

Accepted March 13, 2017

Published April 28, 2017

DOI http://dx.doi.org/10.4238/gmr16029626

Copyright (C) 2017 The Authors. This is an open-access article distributed under the terms of the Creative Commons Attribution ShareAlike (CC BY-SA) 4.0 License.

ABSTRACT. Sexually transmitted infections are an important cause of morbidity among sexually active women worldwide, and have been implicated as cofactors in the pathogenesis of cervical cancer. We investigated the prevalence of human papillomavirus (HPV), Chlamydia trachomatis (CT), and Trichomonas vaginalis (TV), and

Genetics and Molecular Research 16 (2): gmr16029626 
accessed the diversity of HPV in women with normal and abnormal cytology in Manaus, Brazil. We used polymerase chain reaction and HPV genotyping by direct sequencing. The chi-square test was used to calculate the absolute and relative frequencies of the categorical variables, and Fisher's test was used when $\mathrm{P}<0.05$. The level of significance was set at $5 \%$. All statistical analyses were performed using R 2.9.0. There were statistically significant differences in age ( $\mathrm{P}$ $=0.0395)$, education level $(\mathrm{P}=0.0131)$, sexual partners $(\mathrm{P}=0.0211)$, condom use $(\mathrm{P}=0.0039)$, marital status $(\mathrm{P}<0.0001)$, and pregnancy $(\mathrm{P}=0.0003)$ between the normal and abnormal groups. HPV DNA was found in 36.56 and $93.88 \%$ of subjects in the normal and abnormal groups, respectively. A total of 19 genotypes were detected; HPV16 was the most common, followed by HPV58. The percentages of TV and CT DNA were 18.04 and $9.02 \%$ in the normal group, respectively. The percentages of HPV/TV and HPV/CT coinfection were $12.5 \%$ each in women with normal cytology. These findings improve our understanding of HPV, CT, and TV, and the distribution of HPV types, which may be relevant to vaccination strategies for protecting women from the north of Brazil from cervical cancers and precancerous lesions.

Key words: Human papillomavirus; Chlamydia trachomatis; Trichomonas vaginalis; Polymerase chain reaction; Prevalence

\section{INTRODUCTION}

Cervical cancer is the second most common cancer in women in developed countries, and it is estimated that there are 530,000 new cases each year [WHO (World Health Organization), 2016]. In Brazil, it is estimated that there were 16,340 new cases in 2016, with a risk factor of 15 cases per 100,000 women. Excluding non-melanoma skin tumors, cervical cancer is the most prevalent cancer in the north region of Brazil, unlike in other Brazilian regions, with an incidence of 23.97/100.000 women [INCA (Instituto Nacional de Câncer José Alencar Gomes da Silva), 2015]. Persistent infection with human papillomavirus (HPV) is the principal cause of cervical cancer and its precursor, cervical intraepithelial neoplasia.

According to their oncogenic potential, the different types of HPV are classified as low-risk viruses (LR-HPV: 6, 11, 40, 42, 43, 44, 54, 61, 70, 72, 81, and 89), high-risk viruses (HR-HPV: 16, 18, 31, 33, 35, 39, 45, 51, 52, 56, 58, 59, 68, 73, and 82), and probably high-risk viruses (pHR-HPV: 26, 53, and 66) (de Villiers et al., 2004; Muñoz et al., 2006). Both oncogenic and non-oncogenic types of HPV can cause low- and high-grade squamous intraepithelial lesions (LSIL and HSIL, respectively), and may or may not lead to the development of cervical cancer. HPV16 and 18, however, are responsible for 50 and $20 \%$ of all cases of cervical cancer worldwide, respectively (Burk et al., 2009). Although they are very common among young women, the majority of HPV infections are transient, and only a small percentage of women develop a persistent infection (Giuliani et al., 2006).

According to World Health Organization (WHO, 2016), more than one million sexually transmitted infections (STIs) are acquired every day. Every year, approximately 357 million new infections of Chlamydia trachomatis (CT) and Trichomonas vaginalis (TV),

Genetics and Molecular Research 16 (2): gmr16029626 
which are the most common causative agents of STIs, are reported. Pathogens that can be transmitted sexually have been implicated as cofactors in the pathogenesis of cervical cancer (WHO, 2008; INCA, 2015).

The objectives of this study were to investigate the prevalence of HPV, CT, and TV, and to access the diversity of HPV types. We used the polymerase chain reaction and HPV genotyping by direct sequencing in women with normal and abnormal cytology who used health services in Manaus, Amazonas, Brazil.

\section{MATERIAL AND METHODS}

\section{Study groups}

A total of 180 women who used public health services were recruited between October 2013 and April 2014 in Manaus, Amazonas, Brazil. Of those women, 133 were recruited from basic health units and 47 were recruited from the Amazon State Foundation Oncology Control Center (FCECON-AM), which is a reference hospital for cancer treatment in the city. The subjects presented with cytopathological, histopathological, and colposcopic indications of uterine cervical pathologies. All subjects were informed about the objectives, benefits, and risks of this study. Recruitment was by invitation and the subjects were required to answer a socio-economic-cultural questionnaire. Informed consent was obtained from all participants. The study was approved by the Human Research Ethics Committee of the Federal University of Amazonas (CAAE No. 12240113.8.0000.5020).

\section{Sample collection and DNA extraction}

Cervical samples were collected using a cytobrush and re-suspended in a $1.5-\mathrm{mL}$ microtube containing $400 \mu \mathrm{L}$ TE buffer comprising $10 \mathrm{mM}$ Tris-HCl, $\mathrm{pH}$ 8.0, and $1 \mathrm{mM}$ EDTA. They were then immediately transported on ice to the Laboratory of Molecular Diagnosis in the Federal University of Amazonas (UFAM), and stored at $-80^{\circ} \mathrm{C}$ until required.

DNA was extracted from the cervical samples using a QIAamp ${ }^{\circledR}$ DNAMini Kit (Qiagen, Brazil) following the manufacturer instructions. DNA concentrations were estimated using a BioPhotometer D30 spectrophotometer (Eppendorf, Brazil) by measuring the absorbance at 260 and $280 \mathrm{~nm}$. The samples were then stored at $-20^{\circ} \mathrm{C}$ until required for further processing.

\section{Polymerase chain reaction (PCR) for HPV DNA detection and genotyping}

HPV detection was carried out using nested-PCR (nPCR). The first reaction was performed using MY09/MY11 primers (Manos et al., 1989) to amplify a 450-bp fragment. The final volume of the reaction mixture was $25 \mu \mathrm{L}$, comprising $2.5 \mu \mathrm{L}$ DNA, $2.5 \mu \mathrm{L} 10 \mathrm{X}$ reaction buffer, $0.8 \mu \mathrm{L} 50 \mathrm{mM} \mathrm{MgCl}, 0.5 \mu \mathrm{L} 10 \mathrm{mM}$ dNTP, $2.5 \mu \mathrm{L}$ each primer $(5 \mathrm{pmol} / \mu \mathrm{L}), 0.1 \mu \mathrm{L} 5 \mathrm{U} /$ $\mu \mathrm{L}$ Platinum ${ }^{\circledR}$ Taq DNA Polymerase (Invitrogen, Brazil), and 13.6 $\mu \mathrm{L}$ Milli-Q water.

The second reaction was performed using GP5+/GP6+ internal primers (Snijders et al., 1990), which amplified a 150-bp fragment. The final volume of the second reaction mixture was $25 \mu \mathrm{L}$, comprising the sample $(1 \mu \mathrm{L}), 2.5 \mu \mathrm{L} 10 \mathrm{X}$ reaction buffer, $0.8 \mu \mathrm{L} 50 \mathrm{mM} \mathrm{MgCl}_{2}$, $0.5 \mu \mathrm{L} 10 \mathrm{mM}$ dNTP, $2.5 \mu \mathrm{L}$ each primer $(5 \mathrm{pmol} / \mu \mathrm{L}), 0.1 \mu \mathrm{L} 5 \mathrm{U} / \mu \mathrm{L}$ Platinum $^{\circledR}$ Taq DNA Polymerase (Invitrogen, Brazil), and $15.1 \mu \mathrm{L}$ Milli-Q water to complete the final volume. The

Genetics and Molecular Research 16 (2): gmr16029626 
conditions for both reactions were as follows: $95^{\circ} \mathrm{C}$ for $1 \mathrm{~min}$; 40 cycles of $95^{\circ} \mathrm{C}$ for $1 \mathrm{~min}$, $55^{\circ} \mathrm{C}$ for $1 \mathrm{~min}$, and $72^{\circ} \mathrm{C}$ for $1 \mathrm{~min}$; and a final extension for $5 \mathrm{~min}$ at $72^{\circ} \mathrm{C}$.

The PCR products from all positive HPV DNA samples were purified using the ExoSap protocol (GE Healthcare, Brazil) and prepared for sequencing in a final volume of 10 $\mu \mathrm{L}$, comprising the sample $(2 \mu \mathrm{L}), 0.5 \mu \mathrm{L}$ BigDye $^{\mathrm{TM}}$ Terminator, $2 \mu \mathrm{L} 5 \mathrm{X}$ reaction buffer, 0.64 $\mu \mathrm{L} 5$ pmol primers (MY09, MY11, GP5+, or GP6+), and $4.86 \mu \mathrm{L}$ Milli-Q water. The reaction conditions were as follows: $94^{\circ} \mathrm{C}$ for $1 \mathrm{~min}$; and 25 cycles of amplification at $96^{\circ} \mathrm{C}$ for $15 \mathrm{~s}$, $50^{\circ} \mathrm{C}$ for $15 \mathrm{~s}$, and $60^{\circ} \mathrm{C}$ for $4 \mathrm{~min}$.

Sequencing was performed on an ABI 3500 Genetic Analyzer (Applied Biosystems, Foster City, CA, USA) according to the manufacturer recommendations. The sequences were edited and aligned using version 7.2.5 of BioEdit (Hall, 1999), and compared with the sequences included in the GenBank database.

\section{PCR for $C$. trachomatis DNA detection}

C. trachomatis PCR detection was performed using KL1/KL2 primers (Mahony et al., 1993) to amplify a 241-bp fragment of a plasmid DNA of C. trachomatis. The final reaction volume $(25 \mu \mathrm{L})$ comprised $2.5 \mu \mathrm{L}$ DNA, $2.5 \mu \mathrm{L} \mathrm{10X}$ reaction buffer, $1 \mu \mathrm{L} 50 \mathrm{mM}$ $\mathrm{MgSO}_{4}, 0.5 \mu \mathrm{L} 10 \mathrm{mM}$ dNTP, $2.5 \mu \mathrm{L}$ each primer $(5 \mathrm{pmol} / \mu \mathrm{L}), 0.1 \mu \mathrm{L} 5 \mathrm{U} / \mu \mathrm{L}$ Platinum ${ }^{\circledR}$ Taq DNA Polymerase (Invitrogen, Brazil), and $13.4 \mu \mathrm{L}$ Milli-Q. The reaction conditions were as follows: $94^{\circ} \mathrm{C}$ for $30 \mathrm{~s} ; 40$ cycles of amplification at $94^{\circ} \mathrm{C}$ for $30 \mathrm{~s}, 64^{\circ} \mathrm{C}$ for $30 \mathrm{~s}$, and $68^{\circ} \mathrm{C}$ for $2 \mathrm{~min}$; and a final extension for $5 \mathrm{~min}$ at $68^{\circ} \mathrm{C}$.

\section{PCR for $T$, vaginalis DNA detection}

The DNA of T. vaginalis was detected using a touchdown method, and BTUB9/ BTUB2 primers (Madico et al., 1998) were used to amplify a 112-bp fragment of a betatubulin gene of T. vaginalis. The final volume of the reaction mixture was $25 \mu \mathrm{L}$, comprising $2 \mu \mathrm{L}$ DNA, $2.5 \mu \mathrm{L} 10 \mathrm{X}$ reaction buffer, $0.8 \mu \mathrm{L} 50 \mathrm{mM} \mathrm{MgCl}, 0.5 \mu \mathrm{L} 10 \mathrm{mM}$ dNTP, $1 \mu \mathrm{L}$ each primer $(5 \mathrm{pmol} / \mu \mathrm{L}), 0.1 \mu \mathrm{L} 5 \mathrm{U} / \mu \mathrm{L}$ Platinum ${ }^{\circledR}$ Taq DNA Polymerase (Invitrogen, Brazil), and $17.1 \mu \mathrm{L}$ Milli-Q water. The reaction conditions were as follows: $95^{\circ} \mathrm{C}$ for $75 \mathrm{~s} ; 60$ cycles of denaturation at $95^{\circ} \mathrm{C}$ for $45 \mathrm{~s}$; annealing starting at $62^{\circ} \mathrm{C}$ and ending at $52^{\circ} \mathrm{C}$ for $45 \mathrm{~s}$; and extension at $72^{\circ} \mathrm{C}$ for $1 \mathrm{~min}$. The annealing temperature was lowered by $1^{\circ} \mathrm{C}$ every four cycles until it reached $52^{\circ} \mathrm{C}$, and this annealing temperature was then maintained until the end of the cycling process.

All PCR reactions were performed in a Veriti thermocycler (Applied Biosystems, Foster City, CA). Water was included as a negative control, and a previously sequenced and tested sample was used as a positive control. The amplified products for the molecular diagnosis of HPV, C. trachomatis, and T. vaginalis were resolved by electrophoresis on $1.5 \%$ (MY09/MY11), 2.5\% (GP5+/GP6+), 2\% (KL1/KL2), and 2.5\% (BTUB9/BTUB2) agarose gels containing ethidium bromide $(0.5 \mathrm{mg} / \mathrm{mL})$, and visualized with a transilluminator. The images were captured using an Olympus SP-500UZ digital camera.

\section{Statistical analysis}

We used the chi-square test to calculate the absolute and relative frequencies of the

Genetics and Molecular Research 16 (2): gmr16029626 
categorical variables, whereas we used Fisher's test when P values were less than 0.05 . The mean and standard deviations were calculated for the quantitative variables using the KruskalWallis test. The level of significance was set at 5\%. All statistical analyses were performed using the R 2.9.0 software package.

\section{RESULTS}

We recruited 180 women who used the public health service. These women were divided according to cytopathological and histopathological findings. The normal group comprised $133(73.88 \%)$ women who presented with inflammatory cytology, whereas the abnormal group comprised $23(16.11 \%)$ with HSIL and 18 (10\%) with LSIL. Table 1 shows the demographic, clinical, and molecular findings, and the relationship between the normal and abnormal status of the women in this study.

Table 1. Relationship between distribution of the studied risk factors and normal or abnormal cytology status.

\begin{tabular}{|c|c|c|c|c|c|}
\hline \multirow[t]{2}{*}{ Characteristics } & \multicolumn{2}{|c|}{ Abnormal cytology } & \multicolumn{2}{|c|}{ Normal cytology } & \multirow[t]{2}{*}{$P$ value } \\
\hline & $\mathrm{N}$ & $\%$ & $\mathrm{~N}$ & $\%$ & \\
\hline Age (years) & & & & & 0.0395 \\
\hline $16-20$ & 2 & 4.25 & 21 & 15.78 & \\
\hline $21-30$ & 10 & 21.27 & 43 & 32.33 & \\
\hline $31-40$ & 24 & 51.06 & 47 & 35.33 & \\
\hline $41-50$ & 11 & 23.40 & 21 & 15.78 & \\
\hline Education level & & & & & 0.0131 \\
\hline Primary & 21 & 44.67 & 29 & 21.79 & \\
\hline High & 22 & 46.80 & 77 & 56.38 & \\
\hline Graduate & 4 & 8.50 & 22 & 16.53 & \\
\hline Age at first intercourse & & & & & 0.4953 \\
\hline $12-15$ & 20 & 42.55 & 55 & 41.35 & \\
\hline $16-20$ & 25 & 53.19 & 60 & 45.11 & \\
\hline $21-30$ & 2 & 4.25 & 12 & 9.02 & \\
\hline Sexual partners & & & & & 0.0211 \\
\hline $1-2$ & 11 & 23.40 & 51 & 38.34 & \\
\hline $3-4$ & 15 & 31.91 & 47 & 35.33 & \\
\hline$>5$ & 21 & 44.68 & 31 & 23.30 & \\
\hline Condom use & & & & & 0.0039 \\
\hline No & 9 & 19.14 & 57 & 42.86 & \\
\hline Yes & 37 & 78.72 & 76 & 57.14 & \\
\hline Sometimes & 1 & 2.12 & 0 & & \\
\hline Marital status & & & & & $<0.0001$ \\
\hline No & 1 & 31.9 & 57 & 42.85 & \\
\hline Yes & 32 & 68.08 & 75 & 56.38 & \\
\hline Pregnancy & & & & & 0.0003 \\
\hline No & 3 & 6.38 & 27 & 20.30 & \\
\hline Single & 3 & 6.38 & 27 & 20.30 & \\
\hline Double & 7 & 14.89 & 30 & 22.55 & \\
\hline Multiple (3-9) & 34 & 72.34 & 49 & 36.84 & \\
\hline Smoking history & & & & & 0.2574 \\
\hline Never & 32 & 69.08 & 93 & 69.92 & \\
\hline Current & 2 & 4.25 & 10 & 7.51 & \\
\hline In the past & 13 & 27.65 & 22 & 16.54 & \\
\hline Presence of HPV & & & & & $<0.0001$ \\
\hline No & 3 & 6.38 & 85 & 63.90 & \\
\hline Yes & 44 & 93.61 & 48 & 36.09 & \\
\hline Presence of CT & & & & & 0.0364 \\
\hline No & 47 & 100.0 & 121 & 90.97 & \\
\hline Yes & 0 & 0.00 & 12 & 9.02 & \\
\hline Presence of TV & & & & & 0.0039 \\
\hline No & 47 & 100.0 & 109 & 81.95 & \\
\hline Yes & 0 & 0.00 & 24 & 18.04 & \\
\hline
\end{tabular}

HPV: human papillomavirus. CT: Chlamydia trachomatis. TV: Trichomonas vaginalis.

Genetics and Molecular Research 16 (2): gmr16029626 
There were statistically significant differences in age $(P=0.0395)$, education level $(P=0.0131)$, number of sexual partners $(P=0.0211)$, condom use $(P=0.0039)$, marital status $(\mathrm{P}<0.0001)$, and pregnancy $(\mathrm{P}=0.0003)$ between the normal and abnormal groups. The percentages of HPV DNA were $36.56 \%$ (48/133) and 93.88\% (46/49) in the normal and abnormal groups, respectively. The percentages of TV and CT DNA were $18.04 \%(24 / 133)$ and $9.02 \%(12 / 133)$ in the normal group, respectively. Table 2 shows that a total of 19 different HPV types were detected in this study: 7 HR, 6 LR, 3 pHR, and 3 undetermined risk (UR).

\begin{tabular}{|c|c|c|c|c|c|c|c|c|c|}
\hline Geno & & $\mathrm{Abn}$ & ology & & & Norn & $\log y$ & & \\
\hline & & & & & & & & & \\
\hline & & $\mathrm{N}$ & $\%$ & $\mathrm{~N}$ & $\%$ & $\mathrm{~N}$ & $\%$ & $\mathrm{~N}$ & $\%$ \\
\hline $\mathrm{HR}$ & 16 & 20 & 45.45 & 15 & 31.25 & 1 & 16.66 & 2 & 33.33 \\
\hline & 18 & - & - & 1 & 2.08 & - & - & - & - \\
\hline & 31 & 3 & 6.81 & 2 & 4.16 & - & - & - & - \\
\hline & 33 & 4 & 9.09 & 2 & 4.16 & 1 & 16.66 & - & - \\
\hline & 52 & 1 & 2.27 & - & - & - & - & - & - \\
\hline & 58 & 8 & 18.18 & 4 & 8.33 & - & - & - & - \\
\hline & 59 & - & - & 1 & 2.08 & - & - & 1 & 16.66 \\
\hline pHR & 53 & 2 & 4.54 & 3 & 6.25 & - & - & - & - \\
\hline & 66 & - & - & 2 & 4.16 & 1 & 16.66 & 1 & 16.66 \\
\hline & 82 & - & - & 1 & 2.08 & - & - & - & - \\
\hline LR & 6 & 1 & 2.27 & - & - & - & - & - & - \\
\hline & 54 & - & - & 1 & 2.08 & - & - & - & - \\
\hline & 61 & - & - & 3 & 6.25 & - & - & - & - \\
\hline & 70 & - & - & 3 & 6.25 & 1 & 16.66 & 1 & 16.66 \\
\hline & 72 & 1 & 2.27 & 1 & 2.08 & - & - & - & - \\
\hline & 81 & - & - & 2 & 4.16 & - & - & - & - \\
\hline UR & 62 & - & - & 1 & 2.08 & 1 & 16.66 & - & - \\
\hline & 83 & 1 & 2.27 & - & - & - & - & - & - \\
\hline & 102 & 1 & 2.27 & 1 & 2.08 & 1 & 16.66 & 1 & 16.66 \\
\hline Not is & & 2 & 4.54 & 5 & 10.41 & - & - & - & - \\
\hline Total & & 44 & & 48 & & 6 & & 6 & \\
\hline
\end{tabular}

HR: high risk; pHR: probable high risk; LR: low risk; UR: undetermined risk.

The prevalence of HR HPV was $81.6 \%$ (36/44) in the abnormal group and 52.06\% $(25 / 48)$ in the normal group. HPV16 was seen as the most common type in women with abnormal cytology (20/44, 45.45\%), followed by (in order of decreasing frequency): HPV58 (8/44, 18.18\%); HPV33 (4/44, 9.09\%); HPV31 (3/44, 6.81\%); HPV53 (2/44, 4.54\%); and HPV52, 6, 72, 83, and $102(1 / 44,2.27 \%)$. HPV16 was the most common type in the women, even with normal cytology $(15 / 48,31.25 \%)$, followed by (in order of decreasing frequency): HPV58 (4/48, 8.33\%); HPV53, 61, and 70 (3/48, 6.25\%); HPV31, 33, 66, and $81(2 / 48$, 4.16\%); and HPV18, 59, 82, 54, 72, 62, and 102 (1/48, 2.08\%). The percentages of HPV/TV and HPV/CT coinfections were both $12.5 \%(6 / 48)$.

Table 3 shows the HPV types found in the women with abnormal cytology. HPV DNA was detected in $93.61 \%$ (44/47) of women with abnormal cytology, in 36.36\% (16/44) with LSIL, and $63.63 \%(28 / 44)$ with HSIL.

Genetics and Molecular Research 16 (2): gmr16029626 
Table 3. Association between histopathology and human papillomavirus (HPV) positivity.

\begin{tabular}{|c|c|c|c|c|c|}
\hline \multicolumn{2}{|l|}{ Genotypes } & \multicolumn{2}{|c|}{$\operatorname{LSIL}(\mathrm{N}=18)$} & \multicolumn{2}{|c|}{ HSIL $(N=29)$} \\
\hline HR & 16 & $\begin{array}{l}\mathrm{N} \\
6\end{array}$ & $\begin{array}{c}\% \\
33.33\end{array}$ & $\begin{array}{l}\mathrm{N} \\
14 \\
\end{array}$ & $\begin{array}{c}\% \\
48.27\end{array}$ \\
\hline & 31 & & & 3 & 10.34 \\
\hline & 33 & 2 & 11.11 & 2 & 6.89 \\
\hline & 52 & 1 & 5.55 & & \\
\hline & 58 & 4 & 22.22 & 4 & 13.79 \\
\hline $\mathrm{pHR}$ & 53 & & & 2 & 6.89 \\
\hline \multirow[t]{2}{*}{ LR } & 6 & 1 & 5.55 & & \\
\hline & 72 & & & 1 & 3.44 \\
\hline \multirow[t]{2}{*}{ UR } & 83 & 1 & 5.55 & & \\
\hline & 102 & & & 1 & 3.44 \\
\hline \multicolumn{2}{|l|}{ Not identified } & 1 & & 1 & \\
\hline \multicolumn{2}{|l|}{ No HPV detected } & 2 & & 1 & \\
\hline Total & & 18 & & 29 & \\
\hline
\end{tabular}

HR: high risk; pHR: probable high risk; LR: low risk; UR: undetermined risk; LSIL: low-grade squamous intraepithelial lesion; HSIL: high-grade squamous intraepithelial lesion.

\section{DISCUSSION}

In the present study, we determined the prevalence of HPV, CT, and TV infections in women who attended public health services in Manaus, Amazonas, Brazil. We found a HPV detection rate of $36.09 \%$ in women with normal cytology and, as expected, $93.61 \%$ in women with premalignant and malignant cervical lesions. The prevalence of HPV in women with normal cytology was greater than the prevalence rates reported in the last ten years that range from 13 to 35\% among women with normal cytology (Fedrizzi et al., 2008; Fernandes et al., 2009; Lippman et al., 2010; Oliveira et al., 2011; Castro et al., 2011; Rocha et al., 2014; SantosFilho et al., 2016). Similarly, the rates of occurrence described for women with premalignant and malignant cervical lesions in the last 10 years were lower than those demonstrated in this study (de Paula et al., 2007; Paesi et al., 2009; Oliveira-Silva et al., 2011; Gurgel et al., 2013; Freitas et al., 2014). The most prevalent HR-HPV types were 16, 58, 33, and 31, both in the women with normal cytology and those with premalignant and malignant cervical lesions. The results corroborate the data described by Castro et al. (2011) and Rocha et al. (2014) for the State of Amazonia, which demonstrated high genotypic diversity. The prospective studies have shown that HPV-positive women are at higher risk of developing HSIL-like lesions than HPVnegative women (Khan et al., 2005). These risks increase with the presence of HPV types that are phylogenetically related to HPV16 and HPV18. Precancerous lesions can develop in women without any type of cytopathological abnormality up to two years after the detection of HPV16 or HPV18 DNA (Muñoz et al., 2006). Table 3 shows the types of HPV found in women with premalignant and malignant cervical lesions; in the majority of lesions, HSIL type 16 was present and no type 18 was detected in any of the groups. Although HPV infection is very common, less than $10 \%$ of women with an oncogenic type develop some kind of lesion, leading to the belief that the presence of HPV is necessary but not sufficient for the development of these lesions. Therefore, it is a risk cofactor. Among these subjects, there is prolonged use of oral contraceptives, multiparity, tabagism, a high number of sexual partners, and the presence of other STIs such as C. trachomatis, T. vaginalis, and HIV (Smith et al., 2004; INCA, 2015).

The current study showed an association between abnormal cytology and all risk factors related to sexual behavior, suggesting that these cofactors directly influence the development of lesions in HPV-positive women.

Genetics and Molecular Research 16 (2): gmr16029626 
The prevalence of CT infections found in this study for women with normal cytology was $9.02 \%$. This was lower than the rate described by Santos et al. (2003), which was $20.7 \%$ among sexually active women in the city of Manaus, AM, and higher than the prevalence described by Rocha et al. (2014), which was $6.4 \%$ among women seeking public health services in Coari, AM, Brazil. In a study in Manaus involving women with infertility correlated with CT, de Lima Freitas et al. (2011) observed a prevalence of 52.8\%, which was much higher than that described by Fernandes et al. (2014), who reported a prevalence similar to our results $(10.9 \%)$ among women with a history of infertility, who had undergone assisted reproduction techniques. Another important study carried out by Neves et al. (2016) on asymptomatic women aged 14-25 years who used public health services in Manaus showed a prevalence of $13.1 \%$ for CT infections, whereas in women aged 20-25 years this prevalence was $10.8 \%$, as determined by the Digene Hybrid Capture II Test (HCII CT-ID). Our results corroborate the prevalence range found in the rest of Brazil (9.1-14.3\%) (de Paula et al., 2007; Oliveira et al., 2009; Benzaken et al., 2010; Piazzetta et al., 2011; Garcês et al., 2013). CT infection is asymptomatic in almost all women and, if left untreated, can progress to complications such as ectopic pregnancy, pelvic inflammatory disease (PID), and tubal infertility (Golijow et al., 2005). Therefore, it is extremely important to track the pathogen in asymptomatic women to prevent future sequelae.

In this study, we found a prevalence of $18.04 \%$ for TV. This prevalence is higher than the prevalence (12.7\%) described by Rocha et al. (2014) in a similar study performed in Coari, AM. In Brazil, studies that use molecular methods to investigate the prevalence of VT are scarce, which may be explained by the fact that notification of infection with the disease is not considered compulsory, as it is in many other countries (Hobbs and Seña, 2013). Furthermore, because it does not cause any serious sequelae, many clinicians considered it to be more of a nuisance rather than a public health threat. This makes the control of the disease even more difficult (Bowden and Garnett, 1999). The most important point regarding this pathogen is its association with the transmission of acquired human immunodeficiency virus (HIV), pelvic inflammatory disease (PID), infertility, preterm birth, low birth weight of infants born to infected mothers, and cervical cancer (CDC, 2015).

$\mathrm{HPV} / \mathrm{CT}$ coinfection was found in $12.5 \%$ of the women participating in this study and, similarly, HPV/TV coinfection was noted in $12.5 \%$ women. HPV/CT/TV coinfection was found in $6.25 \%$ of the women, and this occurred in women infected with HPV of probable high risk, low risk, and undetermined risk (Table 2).

Thus, the results described in this study highlight the importance of the molecular diagnosis of HPV and of the sexually transmitted pathogens identified as possible cofactors for cervical oncogenesis, as well as the facilitators of other STIs including HIV. Moreover, the verification of the coinfection of these agents clarifies their role in the development of cervical cancer, and promotes the early diagnosis and subsequent treatment of women with these STIs. Information about the distribution of HPV types among women in different Brazilian regions is of paramount importance. This knowledge should be taken into account when considering the use of vaccines that confer protection from the various oncogenic types. At present in Brazil, the HPV vaccination campaign is targeting girls aged 9-13 years by using the quadrivalent HPV vaccine, which only provides immunization against HPV6, 11, 16, and 18. Recently, Joura et al. (2015) established the efficacy and immunogenicity of a nine-valent HPV vaccine that can protect against HPV types $6,11,16,18,31,33,45,52$, and 58 associated with cervical, vulvar, and vaginal cancer. Considering the prevalence of HR-HPV revealed by

Genetics and Molecular Research 16 (2): gmr16029626 
this study (HPV16, 58, 33, and 31), we can infer that the nine-valent vaccine could also be a good option for protecting women from cervical cancers and precancer lesions.

\section{Conflicts of interest}

The authors declare no conflict of interest.

\section{ACKNOWLEDGMENTS}

The authors are grateful to Edson de Freitas Gomes, Dr. Luiz Carlos dos Santos Júnior, Carla Virgínia Lopes Machado, and Larissa de Souza Kirsch for sample collection and interviews, and Maria Ivanilde Silva Araújo, Enedina Nogueira D’Assunção, and Adolfo José da Mota for assisting in the statistical and sequencing analyses. Research supported in part by the Amazonas State Research Support Foundation (FAPEAM). URL: http://www.fapeam. am.gov.br.

\section{REFERENCES}

Benzaken AS, Sales DN, Palheta JI, Junior, Pedrosa VL, et al. (2010). Prevalência da infecção por Clamídia e Gonococo em mulheres atendidas na Clínica de DST da Fundação Alfredo da Matta, Manaus, Amazonas. DST J Bras Doenças Sex Transm. 22: 129-134. http://dx.doi.org/10.5533/2177-8264-201022304

Bowden FJ and Garnett GP (1999). Why is Trichomonas vaginalis ignored? Sex. Transm. Infect. 75: 372-374.

Burk RD, Chen Z and Van Doorslaer K (2009). Human papillomaviruses: genetic basis of carcinogenicity. Public Health Genomics 12: 281-290. http://dx.doi.org/10.1159/000214919

Castro MM, Farias IP, Borborema-Santos CM, Correia G, et al. (2011). Prevalence of human papillomavirus (HPV) type 16 variants and rare HPV types in the central Amazon region. Genet. Mol. Res. 10: 186-196. http://dx.doi. org/10.4238/vol10-1gmr992

CDC (Centers for Disease Control and Prevention) (2015). Sexually Transmitted Diseases Treatment Guidelines. CDC, Atlanta.

de Lima Freitas NS, Borborema-Santos CM, Barroso Serrão das Neves D, Costa de Oliveira CM, et al. (2011). High prevalence detection of Chlamydia trachomatis by polymerase chain reaction in endocervical samples of infertile women attending university hospital in Manaus-Amazonas, Brazil. Gynecol. Obstet. Invest. 72: 220-226. http:// dx.doi.org/10.1159/000324798

de Paula FDF, Fernandes AP, Carmo BB, Vieira DCD, et al. (2007). Molecular detection of Chlamydia trachomatis and HPV infections in cervical samples with normal and abnormal cytopathological findings. Diagn. Cytopathol. 35: 198-202. http://dx.doi.org/10.1002/dc.20629

de Villiers EM, Fauquet C, Broker TR, Bernard HU, et al. (2004). Classification of papillomaviruses. Virology 324: 17-27. http://dx.doi.org/10.1016/j.virol.2004.03.033

Fedrizzi EN, Schulp CG, Menezes ME and Ocampos M (2008). Infecção pelo Papillomavirus Humano em mulheres de Florianópolis, Santa Catarina. J Bras Doenças Sex Transm. 20: 73-79.

Fernandes AMS, Daher G, Nuzzi RXP and Petta CA (2009). Infecção por Chlamydia trachomatis e Neisseria gonorrhoeae em mulheres atendidas em serviço de planejamento familiar. Rev. Bras. Ginecol. Obstet. 31: 235-240. http://dx.doi. org $/ 10.1590 / \mathrm{S} 0100-72032009000500006$

Fernandes LB, Arruda JT, Approbato MS and García-Zapata MTA (2014). Infecção por Chlamydia trachomatis e Neisseria gonorrhoeae: fatores associados à infertilidade em mulheres atendidas em um serviço público de reprodução humana. Rev. Bras. Ginecol. Obstet. 36: 353-358. http://dx.doi.org/10.1590/SO100-720320140005009

Freitas LB, Chen Z, Muqui EF, Boldrini NA, et al. (2014). Human papillomavirus 16 non-European variants are preferentially associated with high-grade cervical lesions. PLoS One 9: e100746. http://dx.doi.org/10.1371/journal. pone. 0100746

Garcês AX, de Martinez AM, Gonçalves CV, Germano FN, et al. (2013). Prevalência de Chlamydia trachomatis e fatores de risco associados à infecção detectada em amostra endocervical. Rev. Bras. Ginecol. Obstet. 35: 379-383. http:// dx.doi.org/10.1590/S0100-72032013000800008

Genetics and Molecular Research 16 (2): gmr16029626 
Giuliani L, Coletti A, Syrjänen K, Favalli C, et al. (2006). Comparison of DNA sequencing and Roche Linear array in human papillomavirus (HPV) genotyping. Anticancer Res. 26 (5B): 3939-3941.

Golijow CD, Abba MC, Mourón SA, Laguens RM, et al. (2005). Chlamydia trachomatis and Human papillomavirus infections in cervical disease in Argentine women. Gynecol. Oncol. 96: 181-186. http://dx.doi.org/10.1016/j. ygyno.2004.09.037

Gurgel AP, Chagas BS, do Amaral CM, Albuquerque EM, et al. (2013). Prevalence and genetic variability in capsid L1 gene of rare human papillomaviruses (HPV) found in cervical lesions of women from North-East Brazil. BioMed Res. Int. 2013: 546354. http://dx.doi.org/10.1155/2013/546354

Hall TA (1999). BioEdit: a user-friendly biological sequence alignment editor and analysis program for Windows 95/98/ NT. Nucleic Acids Symposium Series, London, 41:95-98.

Hobbs MM and Seña AC (2013). Modern diagnosis of Trichomonas vaginalis infection. Sex. Transm. Infect. 89: 434-438. http://dx.doi.org/10.1136/sextrans-2013-051057

INCA (Instituto Nacional de Câncer José Alencar Gomes da Silva) (2015). Ministério da Saúde. Coordenação de Prevenção e Vigilância. Estimativa 2016: incidência de câncer no Brasil. INCA, Rio de Janeiro.

Joura EA, Giuliano AR, Iversen OE, Bouchard C, et al.; Broad Spectrum HPV Vaccine Study (2015). A 9-valent HPV vaccine against infection and intraepithelial neoplasia in women. N. Engl. J. Med. 372: 711-723. http://dx.doi. org/10.1056/NEJMoa1405044

Khan MJ, Castle PE, Lorincz AT, Wacholder S, et al. (2005) The elevated 10-year risk of cervical precancer and cancer in women with Human Papillomavirus (HPV) type 16 or 18 and the possible utility of type-especific HPV testing in clinical practice. J. Natl. Cancer Inst. 97: 1072-1079.

Lippman SA, Sucupira MCA, Jones HE, Luppi CG, et al. (2010). Prevalence, distribution and correlates of endocervical human papillomavirus types in Brazilian women. Int. J. STD AIDS 21: 105-109. http://dx.doi.org/10.1258/ ijsa.2009.008436

Madico G, Quinn TC, Rompalo A, McKee KT, Jr., et al. (1998). Diagnosis of Trichomonas vaginalis infection by PCR using vaginal swab samples. J. Clin. Microbiol. 36: 3205-3210.

Mahony JB, Luinstra KE, Sellors JW and Chernesky MA (1993). Comparison of plasmid- and chromosome-based polymerase chain reaction assays for detecting Chlamydia trachomatis nucleic acids. J. Clin. Microbiol. 31: 17531758.

Manos MM, Ting Y, Wright DK, Lewis AI, et al. (1989). The use of polymerase chain reaction amplification for the detection of genital human papillomaviruses. Cancer Cells 7: 209-214.

Muñoz N, Castellsagué X, González AB and Gissmann L (2006). Chapter 1: HPV in etiology of human cancer. Vaccine. 24S3:S31-S310.

Neves D, Sabidó M, Bôtto-Menezes C, Benzaken NS, et al. (2016). Evaluation of screening for Chlamydia trachomatis among young women in primary health care services in Manaus, Amazonas State, Brazil. Cad. Saúde Pública 32: e00101015.

Oliveira ML, Amorim MMR, Souza ASR, Albuquerque LCB, et al. (2009). Infecção por Chlamydia trachomatis em pacientes com e sem lesões intra-epiteliais cervicais. Rev. Assoc. Med. Bras. 54: 506-512.

Oliveira-Silva M, Lordello CX, Zardo LM, Bonvicino CR, et al. (2011). Human Papillomavirus in Brazilian women with and without cervical lesions. Virol. J. 8: 4. http://dx.doi.org/10.1186/1743-422X-8-4

Paesi S, Serafini EP, Barea F, Madi SRC, et al. (2009). High prevalence of human papillomavirus type 58 in patients with cervical pre-malignant lesions in southern Brazil. J. Med. Virol. 81: 1270-1275. http://dx.doi.org/10.1002/jmv.21410

Piazzetta RC, de Carvalho NS, de Andrade RP, Piazzetta G, et al. (2011). Prevalence of Chlamydia trachomatis and Neisseria gonorrhoea infections in sexual actives young women at a southern Brazilian city. Rev. Bras. Ginecol. Obstet. 33: 328-333.

Rocha DAP, Filho RA, Mariño JM and dos Santos CM (2014). "Hidden" sexually transmitted infections among women in primary care health services, Amazonas, Brazil. Int. J. STD AIDS 25: 878-886. http://dx.doi. org/10.1177/0956462414523742

Santos C, Teixeira F, Vicente A and Astolfi-Filho S (2003). Detection of Chlamydia trachomatis in endocervical smears of sexually active women in Manaus-AM, Brazil, by PCR. Braz. J. Infect. Dis. 7: 91-95. http://dx.doi.org/10.1590/ $\underline{\text { S1413-86702003000200001 }}$

Santos Filho MVC, Gurgel APAD, Lobo CDP, Freitas ACF, et al. (2016). Prevalence of human papillomavirus (HPV), distribution of HPV types and risk factors for infection in HPV-positive women. Genet. Mol. Res. 15: gmr.15028315.

Smith JS, Bosetti C, Muñoz N, Herrero R, et al.; IARC multicentric case-control study (2004). Chlamydia trachomatis and invasive cervical cancer: a pooled analysis of the IARC multicentric case-control study. Int. J. Cancer 111: 431-439. http://dx.doi.org/10.1002/ijc.20257

Genetics and Molecular Research 16 (2): gmr16029626 
Snijders PJF, van den Brule AJF, Schrijnemakers HF, Snow G, et al. (1990). The use of general primers in the polymerase chain reaction permits the detection of a broad spectrum of human papillomavirus genotypes. J. Gen. Virol. 71: 173181. http://dx.doi.org/10.1099/0022-1317-71-1-173

WHO (World Health Organization) (2008). Global incidence and prevalence of selected curable sexually transmitted infections. Avaiable at [http://apps.who.int/iris/bitstream/10665/75181/1/9789241503839_eng.pdf].

WHO (World Health Organization) (2016). Sexually Transmitted Infections (STIs). Avaiable at [http://www.who.int/ mediacentre/factsheets/fs110/en/]. Accessed June 20, 2016.

Genetics and Molecular Research 16 (2): gmr16029626 